\title{
Dietary Approaches to the Treatment of Obesity
}

\author{
Angela Makris, Ph.D., R.D. and Gary D. Foster, Ph.D. \\ Center for Obesity Research and Education, Temple University
}

Popular dietary approaches for weight loss have generated widespread interest and considerable debate. While energy balance remains the cornerstone of weight control (i.e., calories still count), new diets and books promising weight loss by limiting certain foods or macronutrients rather than energy are constantly emerging and hitting the best seller list. Although their names and approaches may change over time, their basic premise has not. They market "success" as a large weight loss over a short period with little effort. Given the allure of a quick fix, overweight and obese individuals are often in search of the next "best" diet. The public's willingness to try diverse and, in some cases, poorly researched dietary approaches underscores their long-standing struggle to control their weight and the need for more effective strategies to help create an energy deficit. In order to develop more effective strategies, it is important to understand the efficacy, health effects, and long-term sustainability of current dietary approaches to weight control.

This article describes various dietary approaches to weight loss (i.e., low-, very low-, and moderate-fat diets, high-protein diets, low-carbohydrate diets, and low glycemic index diets). Descriptions of each dietary strategy are followed by a review of short- and long-term efficacy data from studies published between 2005 and 2011. (See our previous review for a summary of work prior to 2005.)

\section{Low-fat diets}

The Dietary Guidelines for Americans (along with My Pyramid) provides one example of a low-fat (LF) eating plan. ${ }^{1}$ The Dietary Guidelines are based on evidence that eating a LF (20-35\%) diet helps manage weight, promote health, and reduce the risk of chronic disease. The guidelines include recommendations for "foods to reduce" (i.e., saturated and trans fat, cholesterol, sodium, added sugar, refined grains, alcohol) and "foods to increase" (i.e., fruits, vegetables, whole grains, low-fat dairy and protein foods, oils) in order to maximize the nutrient content and health promoting potential of the diet. Other examples of a LF diet are the DASH diet and those recommended by the American Diabetes Association ${ }^{2}$, American Heart Association ${ }^{3}$, and American Cancer Society ${ }^{4}$, as well as commercial programs like Weight Watchers.

\section{Efficacy, health effects, and sustainability}

Low-fat diets are the best studied of all dietary approaches to weight loss. Three large, multi-center, randomized studies (i.e., the PREMIER trial, Diabetes Prevention Program, and the Finnish Diabetes Prevention study) have demonstrated that greater weight loss is achieved in groups consuming LF diets compared to controls receiving standard lifestyle

\footnotetext{
(c) 2011 Elsevier Inc. All rights reserved.

Publisher's Disclaimer: This is a PDF file of an unedited manuscript that has been accepted for publication. As a service to our customers we are providing this early version of the manuscript. The manuscript will undergo copyediting, typesetting, and review of the resulting proof before it is published in its final citable form. Please note that during the production process errors may be discovered which could affect the content, and all legal disclaimers that apply to the journal pertain.
} 
recommendations. ${ }^{5}$ Furthermore, they suggest that consumption of a low-fat, low calorie diet, in the context of intensive group and/or individual counseling, has positive effects on comorbid conditions as long as they are followed. A more detailed description has been reported previously. ${ }^{5}$

More recent studies have reported similar findings. The Look Ahead Trial ${ }^{6}$ was a large multicenter, randomized clinical trial that compared the effects of an intensive lifestyle intervention (ILI) to diabetes support and education (DSE) on the incidence of major cardiovascular disease (CVD) events in overweight or obese individuals with type 2 diabetes. Participants in the ILI group were assigned a calorie restricted LF diet, received frequent behavioral therapy, and extended contact. Those in the DSE group were given standard instruction on 3 occasions each year for eating a healthy diet and engaging in physical activity. Weight loss in the ILI group was significantly greater than the DSE group each year over the course of four years, with maximal weight loss occurring at 1 year (Table 1). Individuals in the ILI group also displayed greater improvements in hemoglobin $A_{1 C}$ $\left(\mathrm{HbA}_{1 \mathrm{C}}\right)$, blood pressure, high density lipoprotein (HDL), and triacylglycerides (TAG) over the course of the study. Other studies prescribing LF diets with treatment phases ranging from $\leq 6$ months to $\geq 12$ months have reported weight losses of approximately $6-11 \mathrm{~kg}$ after $6^{7-9}$ and 12 months ${ }^{10,11}, 4-5 \mathrm{~kg}$ after $24-36$ months $\mathrm{s}^{6,9}$, and $4.7 \%$ initial body weight at 48 months ${ }^{6}$ (Table 1). The Woman's Health Initiative Dietary Modification trial showed that following a LF diet without instruction for calorie restriction can help to maintain weight loss slightly better than following a diet higher in fat. ${ }^{12}$ Taken together, these findings suggest that a LF diet is an effective weight control strategy in the short- and long-term as long as it is followed.

Adherence to a calorie controlled diet appears to be one of the biggest barriers to the longterm success of weight loss maintenance. LF eating is not immune to poor long-term adherence. Researchers have investigated various strategies, from varying the percentage of fat in the diet to matching diets with food preferences, in an attempt to promote better longterm dietary adherence. One study ${ }^{13}$ comparing weight loss and CVD risk factors in individuals consuming calorie controlled $20 \%$ or $30 \%$ fat diets showed that although both diets produced a similar amount of weight loss after 7 months, weight loss was maintained better and CVD risk factors were reduced more after 14 months in those following the 30\% fat diet. It appears that intake was more restrictive in the $20 \%$ fat diet group, making it more difficult to follow over the long-term and resulting in greater weight regain. A limited number of studies have investigated the effects of matching treatment preferences with weight loss outcomes. ${ }^{14-16} \mathrm{~A}$ recent study ${ }^{15}$ found that whether individuals were randomized to their preferred LF diet or not (i.e., standard or lacto-ovo vegetarian), they lost similar amounts of weight after 6 months; however, differences in weight regain patterns emerged after 6 months. Curiously, those who were assigned their preferred diet began regaining weight sooner (i.e., 6 vs. 12 months) and regained more weight (i.e., $4.5 \%$ vs. $2.1 \%$ ) at 18 months than those who were not assigned to their preferred diet. Similar findings were recently reported for both LF and low carbohydrate diets. ${ }^{16}$ Borradaile et al found that the group assigned their preferred diet lost less weight $(-7.7 \mathrm{~kg})$ than the group who did not receive their preferred diet $(-9.7 \mathrm{~kg})$ or who did not report a strong preference at baseline $(-11.2 \mathrm{~kg}) .{ }^{16}$ Given this seemingly counterintuitive finding, it may be useful for future studies to elaborate on "preference" (e.g., is their preference based on a preferred way of eating or on an alternative to their preferred way of eating).

\section{Very-low-fat diets}

Some investigators have suggested that a fat intake of $\leq 20 \%$ of total calories is necessary for optimal health. ${ }^{17,18}$ Diets that provide 10\%-20\% fat are defined as very low-fat. The 
Pritikin and Ornish diets are examples of very low-fat diets. They are primarily plant-based diets (e.g., fruits, vegetables, whole grains, beans, and soy), with limited amounts of reduced fat dairy, eggs, lean meats, and fish. ${ }^{17,18}$ Unlike LF plans which incorporate all foods, the very low-fat diets strongly discourage consumption of foods containing high amounts of refined carbohydrate.

\section{Efficacy, health effects, and sustainability}

A limited number of studies have examined the efficacy of very low-fat diets. In our earlier review $^{5}$, we summarized results from the Lifestyle Heart Trial showing that a very low-fat vegetarian diet-- combined with a behavior modification program including moderate aerobic activity, stress management, and smoking cessation-- was effective in reducing weight and the progression of coronary atherosclerosis. Since this study was published, others have shown that participants following the Ornish diet experienced similar weight loss and improvements in CVD risk factors as participants following other popular diet strategies ${ }^{19,20}$ (Table 1). However, compared to other diets, the Ornish diet showed a trend toward higher attrition ${ }^{19}$ and poorer adherence. ${ }^{20}$ These findings suggest that very low-fat diets may be more difficult to sustain over time.

More recently, Barnard et $\mathrm{al}^{21,22}$ compared weight loss in participants with type 2 diabetes who consumed either a vegan diet (i.e., 10\% energy from fat) or a diet based on the guidelines of the American Diabetes Association diet (i.e., approximately $20 \%-25 \%$ fat). After 22 and 74 weeks, both diets resulted in weight loss and improved glycemic control. Reductions in weight were significantly greater in the vegan group at 22 weeks but not at 74 weeks (Table 1). Dietary adherence was greater in the vegan group at 22 weeks but not at 74 weeks. Participants rated both diets as acceptable. ${ }^{23}$ This research group also compared weight loss in individuals who consumed a vegan (i.e., 10\% energy from fat) and National Cholesterol Education Program (NCEP) low-fat diet (i.e., 30\% energy from fat) for 14 weeks and found that the vegan group had greater weight loss than the NCEP group at 1 and 2 years. ${ }^{11}$ These studies suggest that very low-fat diets are effective in reducing weight and, unlike the studies above, may be sustainable over the long-term.

\section{Moderate-fat diets}

Given that LF diets can contain up to $35 \%$ fat, moderate fat (MF) diets are generally those that contain between $35 \%-45 \%$ fat. Many people equate MF diets with Mediterranean diets but the fat content of Mediterranean diets can vary considerably. Some have reported fat contents as high as $47 \%{ }^{24}$ while others have found them to be as low as $25 \%$ fat $^{25}$; therefore, although some Mediterranean diets can be considered moderate in fat, it should not be assumed that they all are.

\section{Efficacy, health effects, and sustainability}

Previous studies have shown that weight loss was better maintained over time in individuals who followed a MF diet and suggested that it may be easier to adhere to MF diets than LF diets over the long term. ${ }^{5}$ Recent studies that have compared MF (i.e., 35\%-46\% fat) and LF (i.e., 25\%-30\%) diets have reported similar ${ }^{26,27}$ to slightly better ${ }^{28}$ weight losses with MF diets (Table 1). These diets were similar to Mediterranean diets in that they contained a high proportion of monounsaturated fatty acids (MUFAs), primarily from MUFA rich oils, and emphasized high intake of plant foods (i.e., fruits, vegetables, whole grains, legumes, and nuts) and fiber and limited amounts of saturated fat from animal foods. A meta-analysis of 16 randomized controlled trials of the effect of Mediterranean diets on body weight suggested that Mediterranean diets resulted in greater weight losses compared to a control diet, particularly when associated with energy restriction and physical activity. ${ }^{29}$ Of the 
studies included in the meta analysis that reported fat intake, only one study reported total fat intake as less than $35 \%$ fat (i.e., $30 \%$ fat). Compared to LF diets, higher fat, Mediterranean style diets have also been shown to be superior in increasing HDL and reducing atherogenic index (i.e., ratio of total to HDL cholesterol) and C-reactive protein in individuals with hyperlipidemia ${ }^{27}$ or coronary heart disease. ${ }^{28}$ They also are comparable in improving blood pressure, $\mathrm{HDL}, \mathrm{HbA}_{1 \mathrm{C}}$, and fasting glucose and insulin in individuals with type 2 diabetes. 26,28

One study focused on the efficacy of MF diets on weight maintenance. ${ }^{30,31}$ In this study, participants who lost at least $8 \%$ of their initial body weight on an 8 week low energy diet were randomized to one of three ad libitum diets for 6 months: 1) MF, Mediterranean type diet (35\%-45\% fat with > 20\% MUFA); 2) LF (20\%-30\% fat); or 3) control (35\% fat with $>15 \%$ saturated fat). After 6 months, all participants regained weight with no significant differences between groups (MF, $2.5 \mathrm{~kg}$; LF, $2.2 \mathrm{~kg}$; control, $3.8 \mathrm{~kg}$ ). However, body fat regain was lower in the MF and LF groups. The MF diet showed favorable effects on diabetes risk factors (i.e., reduction in fasting insulin and improvements in homeostasis model assessment of insulin resistance [HOMA-IR]) and CVD risk factors (i.e., reduced ratio of low-density lipoprotein [LDL] to HDL).

\section{The high -protein diet}

There is no standard definition of a "high-protein diet;" however, intakes greater than $25 \%$ total energy or $1.6 \mathrm{~g} / \mathrm{kg}$ per day of body weight can be considered high. ${ }^{32}$ The Zone diet (30\% protein, $40 \%$ carbohydrate, and $30 \%$ fat) is an example of a high-protein (HP) diet. The most prominent difference between a HP diet such as the Zone and a low-carbohydrate diet like the Atkins New Diet Revolution is that a HP diet is typically low in fat.

\section{Efficacy, health effects, and sustainability}

Several earlier studies have reported greater weight loss and improvements in body composition (i.e., decreases in waist circumference, waist-to-hip ratio, and intra abdominal adipose tissue and better preservation of lean body mass) in individuals prescribed HP diets than LF diets. These studies have been described in more detail previously. ${ }^{5}$ Given that high waist-to-hip ratios and levels of intra abdominal adipose tissue are positively correlated with certain chronic conditions, interest in HP diets has grown. Findings from more recent studies are mixed. Although several studies have not found significant advantages on body weight and composition 19,33-36, some trials have supported previous findings that diets higher in protein have beneficial effects on weight $\operatorname{loss}^{37-39}$ and body composition. ${ }^{39-41}$ This appears particularly true in individuals with elevated risk of CVD and metabolic syndrome ${ }^{33,42}$ or in individuals who combine a HP diet with resistance training ${ }^{40}$ (Table 1).

There is no clear explanation for these inconsistent results. Inadequate nutrition counseling and poor dietary adherence, particularly in longer studies, may contribute to the lack of differences between dietary groups. Poor long-term adherence has been reported in several studies comparing HP and LF diets on weight loss and body composition ${ }^{19,35-37,39}$ and is not limited to HP diets. For example, Dansinger et al. ${ }^{19}$ reported that only $25 \%$ of participants in each of four dietary groups (i.e., Atkins, Zone, Weight Watchers and Ornish) sustained a clinically meaningful adherence level. McCauley et al ${ }^{39}$ reported that, by 52 weeks, adherence to macronutrient goals declined considerably as did Clifton et al $^{37}$ who found that by 64 weeks, macronutrient intake had shifted to a point at which the diets converged, and there was not a large enough difference in diets to be of significance. As such, data in the latter study were reanalyzed based on actual intakes of protein and 24-hr urinary urea, a marker of protein intake, instead of the assigned intervention. When actual high- and low-protein intake groups were compared, the researchers found that weight loss 
was greater in the HP group than the low-protein group. These findings differed from those in the initial analysis in which no between group differences in weight were observed.

In order to better understand compliance and long-term changes in body composition and blood lipids, Layman et al ${ }^{41}$ compared HP and LF diets in obese but healthy adults over 12 months. This study was divided into 2 phases: 1) 4 months of weight loss; 2) 8 months of weight maintenance. The diets were isocaloric and equal in fat but differed in protein content. The HP group were prescribed $30 \%$ protein (providing $1.6 \mathrm{~g}$ protein $/ \mathrm{kg} / \mathrm{day}$ ) while those in the LF group were prescribed $15 \%$ protein. Each group received a menu plan with meals for each day throughout the 12-month study. Participants met with a dietitian each week who reviewed diet records, answered questions, provided feedback, and measured weight. Adherence to the diet was monitored with plasma TAG, a marker of carbohydrate intake, and urinary urea.

Weight loss did not differ between groups at 4 months; however, the HP group had a greater loss of body fat compared to the LF group. At 4 months, urinary urea, as well as plasma TAG measurements, indicated that both groups were adherent to their macronutrient goals and were consistent with diet records. Adherence in the HP and LF groups also appeared to be good at 8 and 12 months, respectively. At 12 months, there were no differences in changes in weight or lean mass, but the HP group had a greater loss of fat mass. Greater reductions in weight and fat mass (i.e., total and abdominal) have also been observed in studies of obese women with elevated TAG concentrations. ${ }^{33,42}$ Noakes et $\mathrm{al}^{33}$ reported that obese women with elevated TAG concentrations who consumed a HP diet for 12 weeks lost $50 \%$ more body fat than those who consumed an isocaloric LF diet.

Layman et $\mathrm{al}^{41}$ reported that HP diets reduced TAG, HDL cholesterol, and TAG:HDL more than LF diets at 4 months. These effects were sustained at 12 months. Tbe greater reduction in TAG with HP diets is a relatively consistent finding, observed in several studies ${ }^{42}$, including those of obese women with elevated TAG concentrations ${ }^{33}$ and overweight insulin resistant women. ${ }^{39}$ Clifton et al ${ }^{42}$ pooled data from three clinical trials and reported that TAG concentrations decreased to a greater extent on the HP diet compared to the LF diet (i.e., 29\% HP vs. 17\% LF). In addition, this analysis showed that patients with elevated TAG who consumed a HP diet had greater reductions in total cholesterol than those on a LF diet. These researchers also found larger reductions in low-density lipoprotein (LDL) cholesterol in individuals with impaired glucose tolerance (IGT) who were on the HP diet. Taken together, these findings suggest that HP diets might be of some benefit to individuals with or at high risk for diabetes, dyslipidemia, CVD, and metabolic syndrome.

Weight change over the course of 2 years was evaluated in a large study ${ }^{35}$ of 811 overweight adults randomized to one of four calorie-restricted diets: 1) $20 \%, 15 \%$, and $65 \%$, for fat, protein, and carbohydrate, respectively; 2) $20 \%, 25 \%$, and $55 \%$; 3) $40 \%, 15 \%$, and $45 \%$; or 4) $40 \%, 25 \%$, and $35 \%$. Individuals received group lifestyle modification 3 of every 4 weeks for the first 6 months and then bi-weekly from 6 months to 2 years. Individual counseling sessions were also provided every 8 weeks over the course of the study. Weight loss was similar at two years in participants assigned to $15 \%$ and $25 \%$ protein $(3.0 \mathrm{~kg}$ and $3.6 \mathrm{~kg}$, respectively). Adherence to protein intake targets was associated with more weight loss in the high protein group. However, adherence to macronutrient goals diminished after 6 months, indicating that participants had difficulty maintaining specific macronutrient targets over time, despite intensive counseling. All diets reduced risk factors for CVD and diabetes.

Few studies have evaluated HP for weight maintenance. However, a large pan-European study, Diet, Obesity, and Genes (DIOGENES) Project, assessed the efficacy of ad libitum 
MF diets varying in protein and GI for weight maintenance. ${ }^{43}$ After an initial 8-week weight loss program, 773 participants were randomized to one of five LF diets: 1) low protein, low glycemic index (GI); 2) low protein, high GI; 3) high protein, low GI; 4) high protein, high GI; or 5) control diet (i.e., moderate protein, no GI instruction). Dietary counseling was provided biweekly for the first 6 weeks and monthly thereafter. Although participants did not achieve the targeted $12 \%$ difference in protein intake between groups, those in the HP group consumed 5\% more protein as a proportion of total energy than the low protein group. Better weight maintenance was observed in individuals who consumed higher amounts of protein than in those who consumed smaller amounts. Weight regain was $0.9 \mathrm{~kg}$ less in those assigned a high protein diet than those assigned a low protein diet.

There has been concern regarding the overall safety of HP diets. No adverse effects have been observed for markers of kidney or liver function ${ }^{28,34,36,40}$ or bone turnover. ${ }^{33,36}$ However, the effects of HP diets in compromised individuals is unknown.

\section{Low-carbohydrate diets}

The low-carbohydrate (LC) diet is one of the most recognized approaches to weight loss. Many versions of the LC diet exist (i.e., Atkins New Diet Revolution, South Beach, Dukan diet), each with a unique interpretation of optimal LC eating. Unlike LF diets, the FDA has not established a clear definition for "low" carbohydrate. However, LC diets often consist of limited amounts of carbohydrate (20-50 gram/day or about $10 \%$ of calories from carbohydrate), gradually increasing over time, and relatively high amounts of fat (approximately 60\% fat), which differentiates LC diets from HP diets. LC approaches encourage consumption of controlled amounts of nutrient dense carbohydrate containing foods (e.g., low GI vegetables, whole grain products) and eliminate intake of refined carbohydrate. Although consumption of foods that do not contain carbohydrate (e.g., meats, poultry, fish, butter, oil) is not restricted, quality rather than quantity is emphasized.

\section{Efficacy, health effects, and sustainability}

In our earlier review ${ }^{5}$, we described findings from several short-term $(\leq 12$ months $)$ studies comparing the effects of LC and a calorie-controlled, LF diets on weight, body composition, and cardiovascular risk factors in obese adults. In summary, participants who followed a LC diet lost significantly more weight than those who adhered to a LF diet during the first 6 months of treatment. However, differences in weight loss did not persist at 1 year. A metaanalysis published in $2006^{44}$ also found no significant differences in weight loss between diets at 1 year, suggesting that LC diets are as effective as LF diets for weight loss.

Since our last report, several studies comparing weight loss in individuals who consumed LC and LF diets from $1^{19,20,39}$ to 2 years have been published. ${ }^{28,35,45}$ These studies were similar in LC and LF diet prescriptions but varied in the amount of professional support they offered. Among the studies that examined weight loss over a 1-year period, two observed significantly greater weight losses with a LC diet than a LF diet at 6 months ${ }^{20,39}$ but no significant differences in weight were observed between these two diets at 1 year in any of these studies ${ }^{19,20,39}$, supporting earlier findings. Adherence to the macronutrient targets of the diets decreased over time in these studies, particularly in the LC carb group in one study ${ }^{20}$, and attrition was higher in the LC group than the LF group in another study. ${ }^{19}$ This suggests that a LC diet may be more difficult to sustain than a LF diet over time and may explain why there were no differences in weight loss at 1 year.

Findings from studies of longer duration (i.e., 2 years) are mixed. Two studies reported no differences in weight loss between LC and LF diets at 2 years ${ }^{35,45}$, while another reported greater reductions in weight at 2 years with the LC diet compared to a LF diet but similar 
reductions compared to a Mediterranean type diet. ${ }^{28}$ Maximal weight loss occurred at 6 months in these studies, with weight regain beginning between 6 and 12 months. Dietary adherence findings were similar to studies shorter in duration, despite more intensive contact with study staff. The study in which better weight loss outcomes were reported with a LC diet provided participants with food and portion size guidance for the main meal of the day. ${ }^{28}$ Taken together, these findings suggest that LF and LC diets are equally effective in reducing weight.

There have been concerns about the effects of LC diets on CVD risk and bone health. With regard to CVD risk, most studies found that LC diets decreased TAG and very-low-density lipoproteins (VLDL) and increased HDL more than LF diets in the short-term. However, these changes were not sustained in the long-term, with the exception of HDL. Sustained increases in HDL were shown in two studies. ${ }^{39,45}$ Given our current understanding, it does not appear that LC diets trigger any adverse effects on lipid variables. In addition, no differences in body composition or bone mineral density were observed between a LF and LC diet at any point in a 2 year study. ${ }^{45}$

\section{Low-glycemic index (GI) diet}

Carbohydrates vary in the degree to which they raise blood glucose and insulin levels. The term "glycemic index" (GI) refers to a property of carbohydrate-containing food that affects the change in blood glucose following food consumption. ${ }^{46}$ Carbohydrate containing foods are ranked in relation to glucose or white bread, which both have a GI of 100 . Thus, foods with a GI between 0-55 are considered low GI foods, those with a GI of 70 or greater are considered high GI foods, and those that fall between these two ranges are categorized as intermediate GI foods. A variety of factors such as carbohydrate type, amount and type of fiber, degree of processing, cooking, storage, acidity, food structure, and macronutrient content can all affect GI. Glycemic load (GL) is a similar concept but takes into account both the type of carbohydrate and the amount of carbohydrate consumed.

A low GI or GL diet is a unique blend of low-fat and low-carbohydrate concepts.

Recommendations for this dietary approach are based not only on the GI values of foods but also on the overall nutritional content of the diet. ${ }^{47}$ The overall goal of low GI eating is to obtain adequate energy and nutrients without causing large spikes in insulin and blood glucose levels.

\section{Efficacy, health effects, and sustainability}

There has been considerable discussion regarding whether clinicians should recommend low-GI diets to overweight and obese patients. ${ }^{48,49}$ Findings from studies of adults, published in our earlier review ${ }^{5}$, suggested that there were no advantages in terms of weight loss when GI was altered and energy and macronutrient composition were held constant. Findings did suggest, however, that low GI diets may play an important role in the prevention and treatment of metabolic and cardiovascular disease.

More recent studies of adults support previous findings. Although a number of feeding studies suggest that low GI foods increase satiety more than high GI foods ${ }^{50}$, it does not appear that the effect on appetite affects energy intake enough to impact body weight. ${ }^{50}$ One recent study compared the effects of ad libitum low and high GI diets on weight loss in overweight and obese hyperinsulinemic women. ${ }^{51}$ Two additional studies compared energy controlled, isocaloric low and high GL diets, one in adults with at least one criterion for metabolic syndrome ${ }^{51}$, and the other in obese adults with type 2 diabetes. ${ }^{53}$ The ad libitum study was a randomized crossover intervention including two 12-week periods in which women incorporated low GI or high GI foods into their diet. ${ }^{51}$ A difference of 8.4 GI units 
(i.e., 55.5 vs. 63.9) differentiated the low and high GI dietary periods. Simple substitution of low and high GI foods did not reduce energy intake or lead to weight loss. In fact, weight increased during both intervention periods, with no difference between groups.

Klemsdal et al ${ }^{52}$ randomized participants with varying degrees of metabolic syndrome to either a low GL diet or a LF diet. A $500 \mathrm{kcal} /$ day deficit was recommended. Although greater reductions in weight were observed at 3 and 6 months in participants prescribed the low GL diet, 1-year weight loss was almost identical, indicating greater weight regain in the low GL group between 6 and 12 months. Interestingly, at 1 year the change in waist circumference was significantly greater in the LF than in the low GL group $(-5.8 \mathrm{~cm}$ vs. -4.1 $\mathrm{cm})$. Although no differences between groups were observed for systolic pressure, diastolic blood pressure was reduced more in the low GL compared to the LF group $(-4.0 \mathrm{mmHg}$ vs. $-1.1 \mathrm{mmHg})$.

Given their potential to affect glucose and insulin responses, the effects of low and high GI/ GL diets in individuals with diabetes is of particular interest. Therefore, as part of a 40 week lifestyle modification program, overweight and obese men and women with type 2 diabetes were randomized to either a $1500 \mathrm{kcal} \mathrm{LF}$ or low GL diet. ${ }^{51}$ Weight loss and changes in $\mathrm{HbA}_{1 \mathrm{c}}$ were the primary outcome measures in this study. No significant between group differences were observed for reductions in body weight. However, participants prescribed the low GL diet experienced greater reductions in $\mathrm{HbA}_{1 \mathrm{c}}$ than those following the $\mathrm{LF}$ diet at $20(-0.7 \%$ vs. $-0.3 \%)$ and 40 weeks (-0.8\% vs. $-0.1 \%)$. There were no significant differences in fasting glucose, insulin, HOMA-IR, lipids, or blood pressure. While other studies have not observed differences in $\mathrm{HbA1} \mathrm{c}^{54,55}$, findings from this study suggest that low GL diets may provide a metabolic advantage for patients with type 2 diabetes, despite the fact that they were no more effective than LF diets in reducing weight. More research is needed to better understand the metabolic and anthropometric effects of low and high GI diets in individuals with type 2 diabetes and metabolic syndrome. There is some evidence to suggest that individuals with higher insulin secretion lose more weight on a low GL than a high GL diet. $^{56}$

Only a limited number of studies have evaluated the effects of GI on weight maintenance, and findings are mixed. ${ }^{43,57}$ One study reported no difference in body weight in individuals who had lost $6 \%$ of their initial weight and were then randomized to a high GI/GL or low GI/GL diet for 4 months. ${ }^{57}$ Another study showed that weight maintenance was better in participants who followed an ad libitum low GI diet. ${ }^{43}$ Furthermore, participants who consumed a low GI, high protein diet continued to lose weight after initial weight loss, while those who consumed a high GI, low protein diet regained weight.

\section{Summary of findings}

Various dietary strategies can effectively reduce weight, as shown by this review. Those that are coupled with behavior therapy and ongoing support tend to produce longer lasting effects. Improvements in health parameters are observed with each dietary strategy.

Improvements in diabetes and CVD risk factors have been observed with diets ranging from $10 \%$ fat to $45 \%$ fat. HP diets seem to be particularly effective in reducing fat mass and TAG, especially in individuals with dyslipidemia and who are at risk for type 2 diabetes. Likewise, LC diets have been shown to be effective in decreasing TAG and VLDL and increasing HDL. Although low GI diets do not seem to be superior to any other diet for weight loss, there is evidence to suggest that they may provide some metabolic benefit for those with type 2 diabetes. 
Clearly, all of these diets have benefits but they can only be realized when they are followed. A common theme across studies is poor long-term adherence and weight regain. Dansinger et al ${ }^{19}$ found a strong association between diet adherence and clinically significant weight loss, suggesting that "sustained adherence to a diet" rather than "following a certain type of diet" is the key to successful weight management.

\section{Future Directions for Research}

More effective weight loss options are needed to support healthy and sustainable eating behaviors. Randomized control weight loss trials have been designed to assess which diet is best, but perhaps researchers have been asking the wrong question. The "winner take all" mentality does not serve the field or patients well. Rather than asking which is the best diet, investigators should be asking for which type of patients do certain diets work best and how can adherence be improved. Focusing efforts on developing reliable methods for facilitating long-term adherence to both sides of the energy balance equation would be worthwhile and constructive. ${ }^{58}$ Future research might also focus more on behavioral factors that often undermine healthy eating in the long-term. These studies will require large samples that will allow for examination of various behavioral and metabolic subtypes.

\section{References}

1. U.S Department of Agriculture and U.S. Department of Health and Human Services. Dietary Guidelines for Americans, 2010. 7th. Washington, DC: U.S. Government Printing Office; December. 2010

2. Bantle JP, Wylie-Rosett J, Albright AL, Apovian CM, Clark NG, et al. American Diabetes Association. Nutrition recommendations and interventions for diabetes: a position statement of the American Diabetes Association. Diabetes Care. 2008; 31 1:S61-78. [PubMed: 18165339]

3. Lichtenstein AH, Appel LJ, Brands M, Carnethon M, Daniels S, et al. American Heart Association Nutrition Committee. Diet and lifestyle recommendations revision 2006: a scientific statement from the American Heart Association Nutrition Committee. Circulation. 2006; 114:82-96. [PubMed: 16785338]

4. Kushi LH, Byers T, Doyle C, Bandera EV, McCullough M, Gansler T, Andrews KS, Thun MJ. The American Cancer Society 2006 Nutrition and Physical Activity Guidelines Advisory Committee. American Cancer Society Guidelines on Nutrition and Physical Activity for Cancer Prevention: Reducing the Risk of Cancer With Healthy Food Choices and Physical Activity. CA Cancer J Clin. 2006; 56:254-281. [PubMed: 17005596]

5. Makris, AP.; Foster, GD. Dietary Approaches to the Treatment of Obesity. In: Wadden, TA.; Stunkard, AJ.; Berkowitz, RJ., editors. Psychiatric Clinics of North America. Vol. 28. 2005. p. 117-39.

6. Wing RR. Look AHEAD Research Group. Long-term effects of a lifestyle intervention on weight and cardiovascular risk factors in individuals with type 2 diabetes mellitus: four-year results of the Look AHEAD trial. Arch Intern Med. 2010; 170:1566-75. [PubMed: 20876408]

7. Jeffery RW, Levy RL, Langer SL, Welsh EM, Flood AP, Jaeb MA, Laqua PS, Hotop AM, Finch EA. A comparison of maintenance-tailored therapy (MTT) and standard behavior therapy (SBT) for the treatment of obesity. Prev Med. 2009; 49:384-9. [PubMed: 19695283]

8. Riebe D, Blissmer B, Greene G, Caldwell M, Ruggiero L, Stillwell KM, Nigg CR. Long-term maintenance of exercise and healthy eating behaviors in overweight adults. Prev Med. 2005; 40:769-78. [PubMed: 15850878]

9. Svetkey LP, Stevens VJ, Brantley PJ, Appel LJ, Hollis JF, Loria CM, Vollmer WM, Gullion CM, Funk K, Smith P, Samuel-Hodge C, Myers V, Lien LF, Laferriere D, Kennedy B, Jerome GJ, Heinith F, Harsha DW, Evans P, Erlinger TP, Dalcin AT, Coughlin J, Charleston J, Champagne CM, Bauck A, Ard JD, Aicher K. Weight Loss Maintenance Collaborative Research Group. Comparison of strategies for sustaining weight loss: the weight loss maintenance randomized controlled trial. JAMA. 2008; 299:1139-48. [PubMed: 18334689]

Psychiatr Clin North Am. Author manuscript; available in PMC 2012 December 1. 
10. Perri MG, Limacher MC, Durning PE, Janicke DM, Lutes LD, Bobroff LB, Dale MS, Daniels MJ, Radcliff TA, Martin AD. Extended-care programs for weight management in rural communities: the treatment of obesity in underserved rural settings (TOURS) randomized trial. Arch Intern Med. 2008; 168:2347-54. [PubMed: 19029500]

11. Turner-McGrievy GM, Barnard ND, Scialli AR. A two-year randomized weight loss trial comparing a vegan diet to a more moderate low-fat diet. Obesity. 2007; 15:2276-81. [PubMed: 17890496]

12. Howard BV, Van Horn L, Hsia J, Manson JE, Stefanick ML, Wassertheil-Smoller S, Kuller LH, LaCroix AZ, Langer RD, Lasser NL, Lewis CE, Limacher MC, Margolis KL, Mysiw WJ, Ockene JK, Parker LM, Perri MG, Phillips L, Prentice RL, Robbins J, Rossouw JE, Sarto GE, Schatz IJ, Snetselaar LG, Stevens VJ, Tinker LF, Trevisan M, Vitolins MZ, Anderson GL, Assaf AR, Bassford T, Beresford SA, Black HR, Brunner RL, Brzyski RG, Caan B, Chlebowski RT, Gass M, Granek I, Greenland P, Hays J, Heber D, Heiss G, Hendrix SL, Hubbell FA, Johnson KC, Kotchen JM. Low-fat dietary pattern and risk of cardiovascular disease: the Women's Health Initiative Randomized Controlled Dietary Modification Trial. JAMA. 2006; 295:655-66. [PubMed: 16467234]

13. Azadbakht L, Mirmiran P, Esmaillzadeh A, Azizi F. Better dietary adherence and weight maintenance achieved by a long-term moderate-fat diet. Br J Nutr. 2007; 97:399-404. [PubMed: 17298711]

14. Owen K, Pettman T, Haas M, Viney R, Misan G. Individual preferences for diet and exercise programmes: changes over a lifestyle intervention and their link with outcomes. Public Health Nutr. 2010; 13:245-52. [PubMed: 19656436]

15. Burke LE, Warziski M, Styn MA, Music E, Hudson AG, Sereika SM. A randomized clinical trial of a standard versus vegetarian diet for weight loss: the impact of treatment preference. Int J Obes (Lond). 2008; 32:166-76. [PubMed: 17700579]

16. Borradaile, KE.; Halpern, SD.; Wyatt, HR.; Klein, S.; Hill, JO.; Bailer, BA.; Brill, C.; Stein, RI.; Miller, BV.; Foster, GD. Relationship between Treatment Preference and Weight Loss in the Context of a Randomized Controlled Trial. In press

17. Ornish D. Low-fat diets. N Engl J Med. 1998; 338:127, 128-129. [PubMed: 9424579]

18. Freedman MR, King J, Kennedy E. Popular diets: a scientific review. Obes Res. 2001; 9:1S-40S. [PubMed: 11374180]

19. Dansinger ML, Gleason JA, Griffith JL, Selker HP, Schaefer EJ. Comparison of the Atkins, Ornish, Weight Watchers, and Zone diets for weight loss and heart disease risk reduction: a randomized trial. JAMA. 2005; 293:43-53. [PubMed: 15632335]

20. Gardner CD, Kiazand A, Alhassan S, Kim S, Stafford RS, Balise RR, Kraemer HC, King AC. Comparison of the Atkins, Zone, Ornish, and LEARN diets for change in weight and related risk factors among overweight premenopausal women: the A TO Z Weight Loss Study: a randomized trial. JAMA. 2007; 297:969-77. [PubMed: 17341711]

21. Barnard ND, Cohen J, Jenkins DJ, Turner-McGrievy G, Gloede L, Jaster B, Seidl K, Green AA, Talpers S. A low-fat vegan diet improves glycemic control and cardiovascular risk factors in a randomized clinical trial in individuals with type 2 diabetes. Diabetes Care. 2006; 29:1777-83. [PubMed: 16873779]

22. Barnard ND, Cohen J, Jenkins DJ, Turner-McGrievy G, Gloede L, Green A, Ferdowsian H. A lowfat vegan diet and a conventional diabetes diet in the treatment of type 2 diabetes: a randomized, controlled, 74-wk clinical trial. Am J Clin Nutr. 2009; 89:1588S-1596S. [PubMed: 19339401]

23. Barnard ND, Gloede L, Cohen J, Jenkins DJ, Turner-McGrievy G, Green AA, Ferdowsian H. A low-fat vegan diet elicits greater macronutrient changes, but is comparable in adherence and acceptability, compared with a more conventional diabetes diet among individuals with type 2 diabetes. J Am Diet Assoc. 2009 Feb; 109(2):263-72. [PubMed: 19167953]

24. Ferro-Luzzi A, James WP, Kafatos A. The high-fat Greek diet: a recipe for all? Eur J Clin Nutr. 2002; 56:796-809. [PubMed: 12209368]

25. Karamanos B, Thanopoulou A, Angelico F, Assaad-Khalil S, Barbato A, Del Ben M, DimitrijevicSreckovic V, Djordjevic P, Gallotti C, Katsilambros N, Migdalis I, Mrabet M, Petkova M, Roussi $\mathrm{D}$, Tenconi MT. Nutritional habits in the Mediterranean Basin. The macronutrient composition of diet and its relation with the traditional Mediterranean diet. Multi-centre study of the 
Mediterranean Group for the Study of Diabetes (MGSD). Eur J Clin Nutr. 2002; 56:983-91. [PubMed: 12373619]

26. Brehm BJ, Lattin BL, Summer SS, Boback JA, Gilchrist GM, Jandacek RJ, D'Alessio DA. Oneyear comparison of a high-monounsaturated fat diet with a high-carbohydrate diet in type 2 diabetes. Diabetes Care. 2009; 32:215-20. [PubMed: 18957534]

27. Jenkins DJ, Chiavaroli L, Wong JM, Kendall C, Lewis GF, Vidgen E, Connelly PW, Leiter LA, Josse RG, Lamarche B. Adding monounsaturated fatty acids to a dietary portfolio of cholesterollowering foods in hypercholesterolemia. CMAJ. 2010; 182:1961-7. [PubMed: 21041432]

28. Shai I, Schwarzfuchs D, Henkin Y, Shahar DR, Witkow S, Greenberg I, Golan R, Fraser D, Bolotin A, Vardi H, Tangi-Rozental O, Zuk-Ramot R, Sarusi B, Brickner D, Schwartz Z, Sheiner E, Marko R, Katorza E, Thiery J, Fiedler GM, Blüher M, Stumvoll M, Stampfer MJ. Dietary Intervention Randomized Controlled Trial (DIRECT) Group. Weight loss with a lowcarbohydrate, Mediterranean, or low-fat diet. N Engl J Med. 2008; 359:229-41. [PubMed: 18635428]

29. Esposito K, Kastorini CM, Panagiotakos DB, Giugliano D. Mediterranean diet and weight loss: meta-analysis of randomized controlled trials. Metab Syndr Relat Disord. 2011; 9:1-12. [PubMed: 20973675]

30. Due A, Larsen TM, Mu H, Hermansen K, Stender S, Astrup A. Comparison of 3 ad libitum diets for weight-loss maintenance, risk of cardiovascular disease, and diabetes: a 6-mo randomized, controlled trial. Am J Clin Nutr. 2008; 88:1232-41. [PubMed: 18996857]

31. Sloth B, Due A, Larsen TM, Holst JJ, Heding A, Astrup A. The effect of a high-MUFA, lowglycaemic index diet and a low-fat diet on appetite and glucose metabolism during a 6-month weight maintenance period. Br J Nutr. 2009; 101:1846-58. [PubMed: 19079942]

32. Eisenstein J, Roberts SB, Dallal G, Saltzman E. High-protein weight-loss diets: are they safe and do they work? A review of the experimental and epidemiologic data. Nutr Rev. 2002; 1:189-200. [PubMed: 12144197]

33. Noakes M, Keogh JB, Foster PR, Clifton PM. Effect of an energy-restricted, high-protein, low-fat diet relative to a conventional high-carbohydrate, low-fat diet on weight loss, body composition, nutritional status, and markers of cardiovascular health in obese women. Am J Clin Nutr. 2005; 81:1298-306. [PubMed: 15941879]

34. Kerksick CM, Wismann-Bunn J, Fogt D, Thomas AR, Taylor L, Campbell BI, Wilborn CD, Harvey T, Roberts MD, La Bounty P, Galbreath M, Marcello B, Rasmussen CJ, Kreider RB. Changes in weight loss, body composition and cardiovascular disease risk after altering macronutrient distributions during a regular exercise program in obese women. Nutr J. 2010; 9:59. [PubMed: 21092228]

35. Sacks FM, Bray GA, Carey VJ, Smith SR, Ryan DH, Anton SD, McManus K, Champagne CM, Bishop LM, Laranjo N, Leboff MS, Rood JC, de Jonge L, Greenway FL, Loria CM, Obarzanek E, Williamson DA. Comparison of weight-loss diets with different compositions of fat, protein, and carbohydrates. N Engl J Med. 2009; 360:859-73. [PubMed: 19246357]

36. Larsen RN, Mann NJ, Maclean E, Shaw JE. The effect of high-protein, low-carbohydrate diets in the treatment of type 2 diabetes: a 12 month randomised controlled trial. Diabetologia. 2011; 54:731-40. [PubMed: 21246185]

37. Clifton PM, Keogh JB, Noakes M. Long-term effects of a high-protein weight-loss diet. Am J Clin Nutr. 2008; 87:23-9. [PubMed: 18175733]

38. Meckling KA, Sherfey R. A randomized trial of a hypocaloric high-protein diet, with and without exercise, on weight loss, fitness, and markers of the Metabolic Syndrome in overweight and obese women. Appl Physiol Nutr Metab. 2007; 32:743-52. [PubMed: 17622289]

39. McAuley KA, Smith KJ, Taylor RW, McLay RT, Williams SM, Mann JI. Long-term effects of popular dietary approaches on weight loss and features of insulin resistance. Int J Obes (Lond). 2006; 30:342-9. [PubMed: 16158081]

40. Wycherley TP, Noakes M, Clifton PM, Cleanthous X, Keogh JB, Brinkworth GD. A high-protein diet with resistance exercise training improves weight loss and body composition in overweight and obese patients with type 2 diabetes. Diabetes Care. 2010; 33:969-76. [PubMed: 20150293] 
41. Layman DK, Evans EM, Erickson D, Seyler J, Weber J, Bagshaw D, Griel A, Psota T, KrisEtherton P. A moderate-protein diet produces sustained weight loss and long-term changes in body composition and blood lipids in obese adults. J Nutr. 2009; 139:514-21. [PubMed: 19158228]

42. Clifton PM, Bastiaans K, Keogh JB. High protein diets decrease total and abdominal fat and improve CVD risk profile in overweight and obese men and women with elevated triacylglycerol. Nutr Metab Cardiovasc Dis. 2009; 19:548-54. [PubMed: 19179060]

43. Larsen TM, Dalskov SM, van Baak M, Jebb SA, Papadaki A, Pfeiffer AF, Martinez JA, Handjieva-Darlenska T, Kunešová M, Pihlsgård M, Stender S, Holst C, Saris WH, Astrup A. Diet, Obesity, and Genes (Diogenes) Project. Diets with high or low protein content and glycemic index for weight-loss maintenance. N Engl J Med. 2010; 25(363):2102-13. [PubMed: 21105792]

44. Nordmann AJ, Nordmann A, Briel M, Keller U, Yancy WS Jr, Brehm BJ, Bucher HC. Effects of low-carbohydrate vs low-fat diets on weight loss and cardiovascular risk factors: a meta-analysis of randomized controlled trials. Arch Intern Med. 2006; 166:285-93. [PubMed: 16476868]

45. Foster GD, Wyatt HR, Hill JO, Makris AP, Rosenbaum DL, Brill C, Stein RI, Mohammed BS, Miller B, Rader DJ, Zemel B, Wadden TA, Tenhave T, Newcomb CW, Klein S. Weight and metabolic outcomes after 2 years on a low-carbohydrate versus low-fat diet: a randomized trial. Ann Intern Med. 2010; 153:147-57. [PubMed: 20679559]

46. Roberts SB. High-glycemic index foods, hunger, and obesity: is there a connection? Nutr Rev. 2000; 58:163-169. [PubMed: 10885323]

47. Brand-Miller, J.; Wolever, TMS.; Foster-Powell, K.; Colagiuri, S. The New Glucose Revolution. New York, NY: Marlowe \& Co.; 1996. p. 71-94.p. 173-195.

48. Pawlak DB, Ebbeling CB, Ludwig DS. Should obese patients be counseled to follow a lowglycaemic index diet? Yes. Obes Rev. 2002; 3:235-243. [PubMed: 12458970]

49. Raben A. Should obese patients be counseled to follow a low-glycaemic index diet? No. Obes Rev. 2002; 3:245-256. [PubMed: 12458971]

50. Ford H, Frost G. Glycaemic index, appetite and body weight. Proc Nutr Soc. 2010; 69:199-203. [PubMed: 20423537]

51. Aston LM, Stokes CS, Jebb SA. No effect of a diet with a reduced glycaemic index on satiety, energy intake and body weight in overweight and obese women. Int J Obes (Lond). 2008; 32:1605. [PubMed: 17923862]

52. Klemsdal TO, Holme I, Nerland H, Pedersen TR, Tonstad S. Effects of a low glycemic load diet versus a low-fat diet in subjects with and without the metabolic syndrome. Nutr Metab Cardiovasc Dis. 2010; 20:195-201. [PubMed: 19502017]

53. Fabricatore AN, Wadden TA, Ebbeling CB, Thomas JG, Stallings VA, Schwartz S, Ludwig DS. Targeting dietary fat or glycemic load in the treatment of obesity and type 2 diabetes: A randomized controlled trial. Diabetes Res Clin Pract. 2011; 92:37-45. [PubMed: 21208675]

54. Wolever TM, Gibbs AL, Mehling C, Chiasson JL, Connelly PW, Josse RG, Leiter LA, Maheux P, Rabasa-Lhoret R, Rodger NW, Ryan EA. The Canadian Trial of Carbohydrates in Diabetes (CCD), a 1-y controlled trial of low-glycemic-index dietary carbohydrate in type 2 diabetes: no effect on glycated hemoglobin but reduction in C-reactive protein. Am J Clin Nutr. 2008; 87:11425. [PubMed: 18175744]

55. Davis NJ, Tomuta N, Schechter C, Isasi CR, Segal-Isaacson CJ, Stein D, Zonszein J, Wylie-Rosett J. Comparative study of the effects of a 1-year dietary intervention of a low-carbohydrate diet versus a low-fat diet on weight and glycemic control in type 2 diabetes. Diabetes Care. 2009; 32:1147-52. [PubMed: 19366978]

56. Pittas AG, Das SK, Hajduk CL, Golden J, Saltzman E, Stark PC, Greenberg AS, Roberts SB. A low-glycemic load diet facilitates greater weight loss in overweight adults with high insulin secretion but not in overweight adults with low insulin secretion in the CALERIE Trial. Diabetes Care. 2005; 28:2939-41. [PubMed: 16306558]

57. Philippou, E.; Neary, NM.; Chaudhri, O.; Brynes, AE.; Dornhorst, A.; Leeds, AR.; Hickson, M.; Frost, GS. Obesity. Vol. 17. Silver Spring: 2009. The effect of dietary glycemic index on weight maintenance in overweight subjects: a pilot study; p. 396-401.

58. Dansinger ML, Schaefer EJ. Low-fat diets and weight change. JAMA. 2006; 295:94-5. [PubMed: 16391222] 


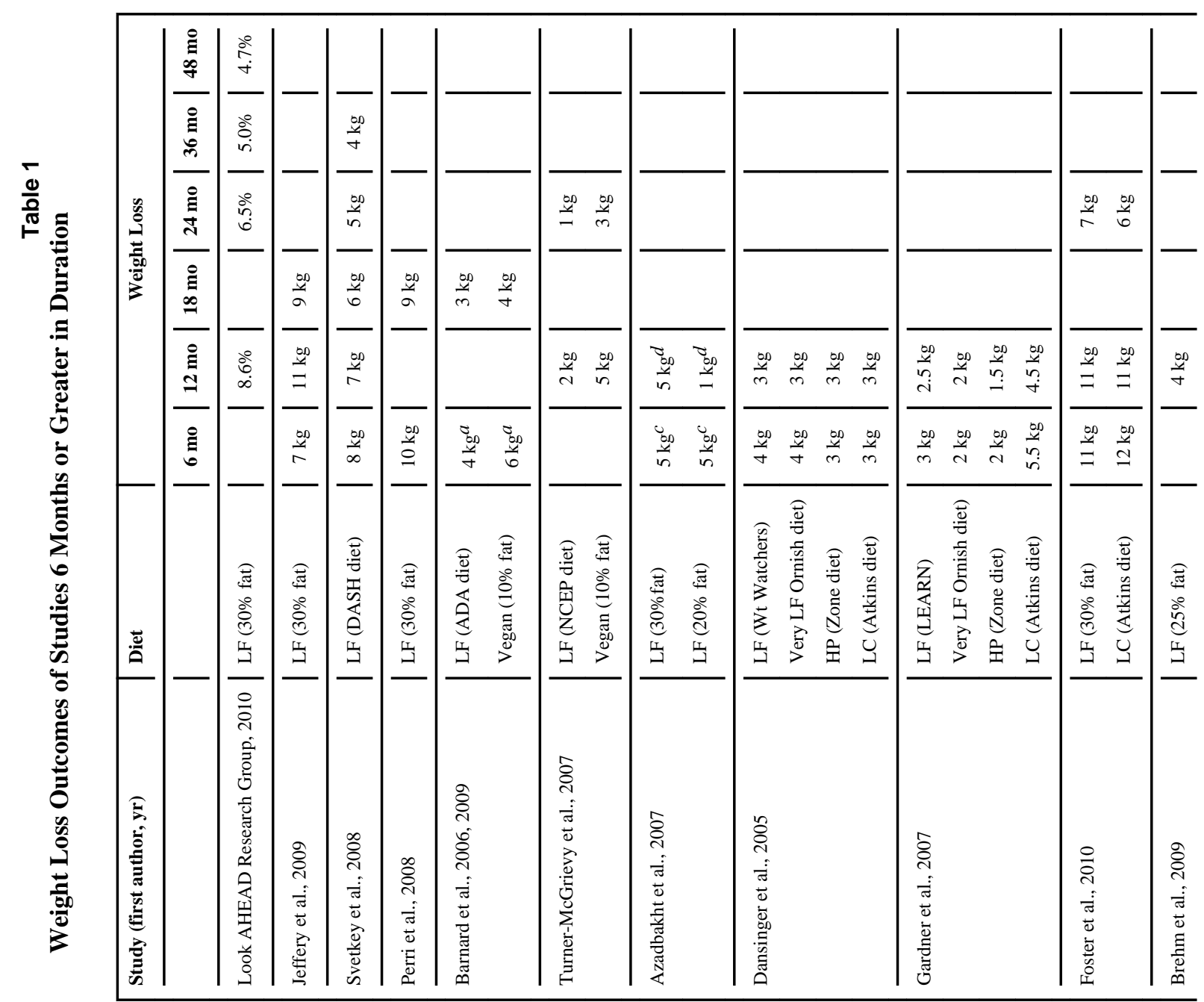


